\title{
SUPRAPUBIC CATHETERISATION AFTER SPINAL CORD INJURY: A FOLLOW-UP REPORT
}

\author{
By R. C. Peatfield, M.D., M.R.C.P., A. A. Burt, M.R.C.P. and P. H. \\ SMITH, F.R.C.S. \\ Spinal Injuries Unit, Pinderfields General Hospital, Wakefield, Yorkshire
}

Summary. The spinal injury patients who were initially treated by suprapubic catheterisation and reported from this unit in 1976 have been reviewed.

Fifteen had died by early 1982; only in two cases from renal causes. All but one of the 23 survivors seen has a normal blood urea, and i 5 have normal intravenous pyelograms. Eight patients have abnormal IVPs; the abnormalities were insignificant in four, and have been treated in two. Two patients have unilateral nonfunctioning kidneys.

These results suggest that no long term ill effects result from the technique. In view of its considerable administrative advantages suprapubic urinary drainage should become more widely used.

Key words: Paraplegia; Neuropathic bladder; Suprapubic catheterisation; Bladder neck obstruction; Kidney failure.

\section{Introduction}

IT HAS been clear since the Second World War that it is essential to institute bladder drainage during the first week after severe spinal cord injury, but controversy still surrounds the best means to do this. Continuous drainage by a urethral catheter is the simplest to organise and it remains the most commonly used method, but it is associated with a very high incidence of urinary tract infection (Guttmann, I976).

Intermittent urethral cathetisation, (Guttmann and Frankel I966; Pearman et al., 1976) reduces the incidence of infection but has many disadvantages. If the catheterisation is always to be performed by medical staff the demands on manpower resources are so great that it can only be performed every 8 hours; the limited bladder capacity thus necessitating restriction of the patients fluid intake to $1500 \mathrm{mls}$ in 24 hours (Pearman et al., 1976). Prolonged storage of urine in the bladder is, of course, a potent predisposition to infection, exacerbated by the low fluid intake. Repeated instrumentation of the urethra and prostatic bed may also lead to acute or chronic infection.

To overcome these difficulties Cook and Smith (1976) and Smith, Cook and Burt (1976) introduced fine-bore suprapubic catherisation to drain the bladder after spinal cord injury. This technique allows the bladder to distend and to be evacuated as often as is required: the frequency depends on the bladder capacity and the patients' fluid intake. There is evidence from experimental animal studies that repetitive expansion and contraction of the bladder preserves normal responsiveness of the bladder musculature (Bradley et al., I963). The undisturbed urethra allows spontaneous voiding by the patient as soon as neurological recovery permits. 
Preservation of sterile urine in the early stages is also believed to encourage spontaneous bladder emptying.

Smith, Cook and Burt (1976) reported 4I male patients who had been managed by percutaneous suprapubic catheterisation. Drainage of the bladder could be maintained for an average of 8 weeks, and the urine remained sterile throughout without the use of antibiotics in almost half the cases. It was concluded that the technique gave encouraging results, and was considered less demanding to administer than intermittent catheterisation. Since that report Fam et al. (1978) have used suprapubic catheters in seven out of a series of 120 patients with similar results.

The patients in our original series have been receiving regular follow up (including IVPs) by a urologist after discharge from the Spinal Unit. Paraplegic patients having difficulty in voiding urine, or those with high residual volumes, underwent resection of the bladder neck and division of the external sphincter, whereas many tetraplegic patients were given an indwelling urethral catheter.

\section{Methods}

In the present study the patients in the original series were followed up to establish

I. the numbers of patients dying of kidney related causes; and

2. the present renal function in the survivors.

Strenuous attempts were made to trace all the patients and to establish the results of recent measurements of blood urea and creatinine, and of an IVP in the survivors, and the causes of death in the remainder. The Life table was prepared by the method of Cutler and Ederer (I958).

\section{Results}

Of the 4I patients originally studied I 5 were dead by early I 982 , while 26 were still alive. The Life table is shown in Figure I.

\section{Dead patients}

The causes of death in the 15 patients are related to the time since spinal injury in Table I. Nine of the 15 patients had autopsies and the causes of death in the remainder were ascertained from the patients' notes and/or death certificates.

Two of the deaths could be attributed to renal causes:

Case 5. A man aged 42 was injured in February I 968 when his Land Rover overturned, causing a fracture at TII/I2. His blood urea was $2.1 \mathrm{~m} . \mathrm{mol} / \mathrm{l}$ in November 1968. He was transferred to a Chronic Sick Hospital in April I 969 with condom drainage, and an IVP in December 1969 was considered normal. He was not seen after this, and died in September 1973 without an autopsy. His death certificate attributed death to septicaemia following urinary tract infection.

Case 7. A 66-year-old diet controlled diabetic with a past history of transient cerebral ischaemic attacks, had a road traffic accident in December 1967, and developed a C6-8 tetraplegia without radiological evidence of fracture. Three days 


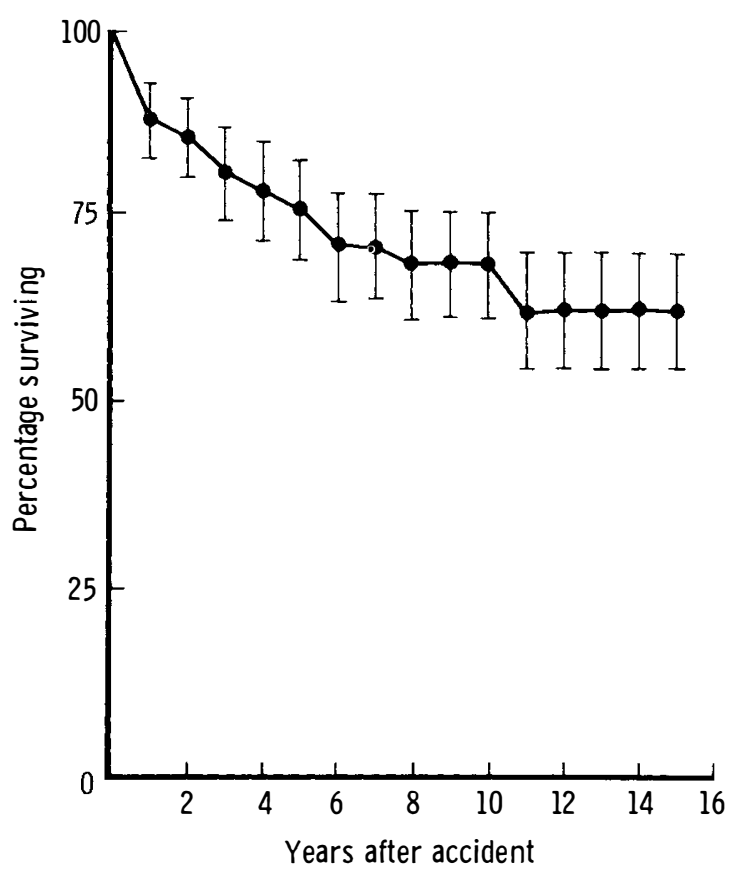

FIG. I

TABLE I

Cause of death

\begin{tabular}{|c|c|c|c|c|c|}
\hline & $\begin{array}{l}\text { Under } \\
\text { one } \\
\text { month }\end{array}$ & $\begin{array}{l}\text { One } \\
\text { month } \\
\text { to one } \\
\text { year }\end{array}$ & $\begin{array}{l}\text { One to } \\
\text { five } \\
\text { years }\end{array}$ & $\begin{array}{l}\text { Over } \\
\text { five } \\
\text { years }\end{array}$ & Total \\
\hline $\begin{array}{l}\text { Pulmonary embolus } \\
\text { Acute pyelonephritis } \\
\text { Pneumonia } \\
\text { Myocardial infarction } \\
\text { or failure } \\
\text { Toxaemia from bed sores } \\
\text { Toxaemia from urinary tract } \\
\text { Suicide }\end{array}$ & $\begin{array}{l}\underline{4} \\
- \\
=\end{array}$ & $\begin{array}{l}E \\
-\end{array}$ & $\begin{array}{l}2^{\star} \\
\mathrm{I}^{\star} \\
-\end{array}$ & $\begin{array}{l}\bar{Z} \\
2_{\star}^{\star} \\
\frac{2^{\star}}{I^{\star}} \\
I^{\star}\end{array}$ & $\begin{array}{r}4 \\
\mathrm{I} \\
\mathrm{I} \\
\mathrm{I} \\
\mathrm{I} 5\end{array}$ \\
\hline
\end{tabular}

* These patients did not have post mortem examinations

after admission he had a right sided cerebro-vascular lesion with dysphasia. It became clear that rehabilitation would not prove possible, and a urethral catheter was inserted and he was transferred to a Geriatric Hospital in February 1968. Nine days later he developed pyrexia, was given Ampicillin but there was no bacterial assessment. He died 4 days later. Autopsy showed bilateral inflammation of the renal pelves and slight pulmonary congestion. Death was certified as being due to acute pyelo-nephritis. 
Survivors

The 26 survivors have been followed up for a minimum of 8 years after their injury. No data at all are available for two of these patients, known to be alive, who have refused to attend for follow up. One other patient is under the care of a urologist elsewhere and we have the result of an IVP but not of blood tests.

There are, therefore, 23 patients in whom blood urea levels taken between September I98I and April I982 are available. In 22 of these the result is within normal limits $(<7.1 \mathrm{~m} \cdot \mathrm{mol} / \mathrm{l})$. The only exception was in one patient with a urea of 7.5 with a normal creatinine level $(89 \mu \mathrm{mol} / \mathrm{l})$. In Figure 2 the last recorded blood urea is related to the time since the accident in the living, lost and dead patients. Plasma creatinine estimations were available in 20 patients. In I9 the figure was less than I $25 \mu \mathrm{mol} / 1$ the only exception being the figure of $190 \mu \mathrm{mol} / \mathrm{I}$ in a patient with a urea of $4 . \mathrm{m} \cdot \mathrm{mol} / \mathrm{l}$ and a normal IVP.

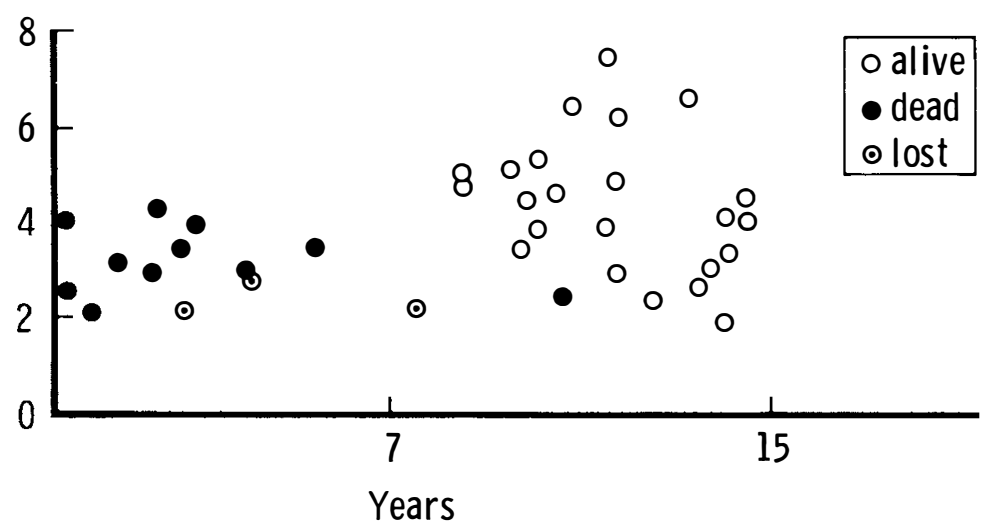

FIG. 2

Last recorded blood urea (m.mol/l)

Recent IVPs were available in 23 patients. The two patients (mentioned above) refused to be followed up, and one patient with an ileal conduit was allergic to intravenous contrast medium. His isotope renogram in September I98I, however, showed some impairment of excretion but contrast medium in the conduit showed no reflux. His blood urea was $6.5 \mathrm{~m} . \mathrm{mol} / \mathrm{l}$ and plasma creatinine $100 \mu \mathrm{mol} / \mathrm{l}$.

The results of the IVPs are shown in Table II. All were performed during or since December 1981 except for one in August 1980, and one each in January, March and October I98I.

In two of the three patients with slight bilateral renal and ureteric dilation this is considered insignificant, and the third has had a bladder neck resection and division of the external sphincter with improvement shown on a further IVP. The renal stones in one of the two patients are not considered significant, and the other patient has recently had the stones removed.

Three patients had unilateral non-functioning kidneys. One patient, injured in August 1970, had a routine IVP in May I971 which showed 
TABLE II

Results of intravenous pyelograms

\begin{tabular}{lr}
\hline Normal & I 5 \\
Slight bilateral dilatation of pelvis and ureter only & 3 \\
Unilateral kidney stones & 2 \\
One non-functioning or poorly functioning kidney & 3 \\
Poor drainage on isotope renogram & I \\
No information & 26 \\
Total & 26
\end{tabular}

bilateral ureteric dilatation with very poor function on the right. An indwelling catheter was inserted, and the IVP improved; a bladder neck resection and division of the external sphincter was performed in June 1972 because his catheter was bypassing. IVPs in October 1972, January 1974, April I 975 and July 1978 showed some hydro-nephrosis and renal atrophy on the right. In I979, however, he complained of some difficulty in passing urine, and a further bladder neck and external sphincter resection was performed. The December I98I IVP showed a non-functioning right kidney with dilatation on the left, and he underwent bilateral ureteric reimplantations in February I982. At that time his urea was $6.3 \mathrm{~m} . \mathrm{mol} / \mathrm{l}$. A further IVP in August 1982 showed improvement in the left hydronephrosis, but only a faint nephrogram on the right.

The second patient, inured in 1969 , lost function of the right kidney between 20 March and I 8 April I 970, and had a right uretero-pyelolithotomy on 24 April 1970 with some recovery of right renal function. A further stone was removed from the right ureter in July 1970. In August I97I, however, there was no excretion from the right kidney, and this has persisted ever since. His biochemistry remains normal.

The third patient, injured in 1972, remained well until a routine IVP in January I98I, which showed reflux and atrophic changes in the right kidney. A bladder neck resection and division of the external sphincter was performed in May I98I. A further IVP in March 1982 shows atrophy on the right side, but bilateral excretion, and his biochemistry is again normal.

The patients' present urinary drainage system is shown in Table III. Two-thirds of the surviving paraplegics, but less than half of the tetraplegic patients have condom drainage. All three patients with urinary stones have indwelling urethral catheters, whereas the two with non-functioning kidneys, and the three with pelvic dilatation all had condoms. One patient developed retention of urine, a right hemianaesthesia and mild right hemi-

TABLE III

The current urinary drainage system

\begin{tabular}{lccccc}
\hline & Dead & $\begin{array}{c}\text { Condom } \\
\text { now }\end{array}$ & $\begin{array}{c}\text { Catheter } \\
\text { now }\end{array}$ & $\begin{array}{c}\text { Ileal } \\
\text { conduit }\end{array}$ & Total \\
\hline Tetraplegics & 9 & 2 & 3 & I & I 5 \\
Paraplegics & 6 & I2 & 6 & I & 25 \\
Total & & & & 40 \\
\hline
\end{tabular}


paresis after a head injury in a mining accident. Although TI was tender there was no fracture, and no sensory loss on the left. He is now able to void normally, and has been omitted from the table.

\section{Discussion}

The Io year survival rate in our patients is 68 per cent, and the I 5 year survival rate 63 per cent. Comparable data from other centres relating to patients treated by different methods of bladder management is, unfortunately, not easily available. They cannot be culled accurately from the available statistics from Stoke Mandeville Hospital (Guttmann, I976). Four of our patients died within a month of their accident from a massive pulmonary embolus; this was before the introduction of any routine anticoagulant prophylaxis.

Tribe and Silver (I969), from Stoke Mandeville Hospital published careful post mortem studies on spinal injury patients who had died in the previous 20 years. Of I I 7 post mortem examinations performed more than 3 months after injury in which death was attributed to the paraplegia, in 86 (73.5 per cent) death resulted from renal failure due to pyelonephritis, and the majority also had amyloidosis. No more recent post mortem series have been published; nevertheless our figure of only two renal deaths in 4I patients compares very favourably with this experience.

There is no evidence of a rising trend in blood urea. Fifteen out of the 24 surviving patients had normal IVPs, and of the remainder five had potentially treatable abnormalities. The only irreversible changes were found in the patients with condom drainage.

Pearman (1976) has followed 75 male patients treated by intermittent urethral catheterisation for a mean of 3 years. Four patients had had unilateral or bilateral hydronephrosis that had responded to bladder neck resection, and one further patient had moderate dilatation of the renal parenchyma despite an ileal conduit. One patient had traumatic thrombosis of the renal artery. Their policy of instilling antibiotics into the bladder and the much shorter period of follow-up, however, make a comparison with this series difficult. Only one of our patients had major irreversible changes a minimum of 8 years after the accident.

In a recent controlled prospective comparison of suprapubic catheterisation intermittent urethral catheterisation Grundy et al. (I983), have confirmed that suprapubic catheters are very much easier for patients, nurses and doctors to manage, and have found no short-term ill-effects. They have also calculated that suprapubic catheters cost $£ 7.70$ per week whereas intermittent urethral catheterisation costs $£$ IO 40 per week.

It is clear from our study that renal function in the long term is preserved just as well with suprapubic catheterisation, even without the routine use of local or systemic antibiotics. It may well become the treatment of choice in all spinal injury units.

\section{RÉSUMÉ}

Nous avons passés en revue les 4 I patients blessés a la moelle épinière qui ont été traités dès le commencement avec le sondage sus-pubis et dont avons rendu compte a 1976.

Au debut de l'année I982 nous avons trouvés que is étaient morts, seulement deux à cause d'une maladie rénal. 
Vingt-deux des 23 survivants que nous avons examinés avaient une urée sanguine normal, et 15 ont pression intravenieux normal. Huit patients avaient une pression intravenieux anormal. Chez 4 patients le charactère anormal était insignificant. A 2 patients il a été traité. Deux patients avaient un rein qui ne functionne pas.

Ces résultats donnent l'idée que cette technique n'occasionne pas des effects pernicieux a long terme.

En raison des avantages de l'administration du sondage sus-pubis, cette technique devrait etre employé plus largement.

\section{ZUSAMMENFASSUNG}

Man hat die 4I querschnittgelähmten Patienten, die erstens durch suprapubischen Katheter behandelt und aus dieser Station berichtet waren, wider untergesucht.

Früh in Jahre I 982 waren I5 gestorben, nur in zwei Fällen vor Nierengründen. Alle, ausser einem, der 23 gesehen, haben einen normalen Blutharnstoff, und 15 haben ein normales IVP. Acht Patienten haben ein abnormales IVP-in 4 waren die Unregelmässigkeiten unbedeutend, und in 2 waren behandelt. Zwei Patienten haben einseitigen nichtarbeitenden Nieren.

Diese Ergebnisse deuten an, dass keine langzeitigen üblen Folge aus dieser Methode folgen. Mit Rücksicht auf die bedeutenden administrativen Vorteile, suprapubishces Urinabfliessen sollte mehr allgemein benutzt werden.

Acknowledgements. We are grateful to Mrs C. Allerton and Mrs C. Holmes for secretarial assistance. Mr D. J. Grundy kindly reviewed the manuscript.

\section{REFERENCES}

Bradley, W. E., Chou, S. N. \& French, L. A. (1963). Further Experience with the Radio Transmitter Receiver Unit for the Neurogenic Bladder. F. Neurosurgery, 20, 953-960.

Cook, J. B. \& SMith, P. H. (I976). Percutaneous Suprapubic Cystostomy after Spinal Cord Injury. British fournal of Urology, 48, I I9-12 I.

Cutler, S. J. \& Ederer, F. (1958). Maximum Utilization of the Life Table Method in Analyzing Survival. F. Chronic Diseases, 8, 699-712.

Fam, B. A., Rossier, A. B., Blunt, K., Gabilondo, F. B., Sarkarati, M., Sethi, J. \& Yalla, S. V. (1978). Experience in the Urological Management of I 20 Early Spinal Cord Injury Patients. Fournal of Urology, 119, 485-487.

Grundy, D. J., Fellows, G. J., Gillett, P., Nuseibeh, I. \& Silver, J. R. (1983). A Comparison of Fine-Bore Suprapubic and an Intermittent Urethral Catheterisation Regime after Spinal Cord Injury. (In press.)

Guttmann, L. (1976). Spinal Cord Injuries-Comprehensive Management and research. Oxford: Blackwell.

Guttmann, L. \& Frankel, H. (I966). The Value of Intermittent Catheterisation in the Early Management of Traumatic Paraplegia and Tetraplegia. Paraplegia, 4, 63-83.

Pearman, J. W. (1976). Urological Follow-up of 99 Spinal Cord Injured Patients initially managed by Intermittent Catheterisation. British fournal of Urology, 48, 297-310.

Smith, P. H., Cook, J. B. \& Burt, A. A. (I976). Percutaneous Cystostomy in ParaplegiaA Follow-up of $4 \mathrm{I}$ patients. Paraplegia, I4, I35-I 37.

TRIBE, C. R. \& Silver, J. R. (I 969). Renal Failure in Paraplegia. London: Pitman Medical. 